\title{
Combustion of Coal-Gas Fuels in a Staged Combustor
}

T. J. Rosfjord and J. B. McVey

United Technologies Research Center

DO NOT MICROFILM United Technologics Corporation

R. A. Sederquist

Power Systems Division

United Technologies Corporation

and

D. F. Schultz

National Aeronautics and Space Administration Lewis Research Center

Work performed for

\section{U.S. DEPARTMENT OF ENERGY}

Fossil Energy

Office of Coal Utilization and Extraction

Prepared for

Joint Power Conference

Denver, Colorado, October 17-21, 1982 


\section{DISCLAIMER}

This report was prepared as an account of work sponsored by an agency of the United States Government. Neither the United States Government nor any agency Thereof, nor any of their employees, makes any warranty, express or implied, or assumes any legal liability or responsibility for the accuracy, completeness, or usefulness of any information, apparatus, product, or process disclosed, or represents that its use would not infringe privately owned rights. Reference herein to any specific commercial product, process, or service by trade name, trademark, manufacturer, or otherwise does not necessarily constitute or imply its endorsement, recommendation, or favoring by the United States Government or any agency thereof. The views and opinions of authors expressed herein do not necessarily state or reflect those of the United States Government or any agency thereof. 


\section{DISCLAIMER}

Portions of this document may be illegible in electronic image products. Images are produced from the best available original document. 

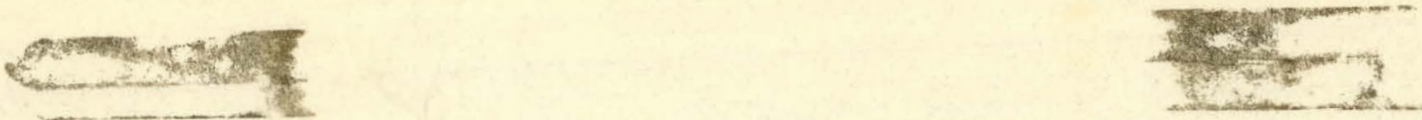

\section{NOTICE}

This report was prepared to document work sponsored by the United States Government. Neither the United States nor its agent, the United States Department of Energy. nor any Federal employees. nor any of theil contractors, subcontractors or their employees. makes any warranty, express or implied. or assumes any legal liability or responsibility for the accuracy, completeness, or usefulness of any information, apparatus, product or process disclosed. or represents that its use would not infringe privately owned rights. 


\section{Combustion of Coal-Gas Fuels in a Staged Combustor}

T. J. Rosfjord and J. B. McVey

United Technologies Research Center

United Technologies Corporation

East Hartford, Connecticut

R. A. Sederquist

Power Systems Division

United Technologies Corporation

South Windsor, Connecticut

and

D. F. Schultz

National Aeronautics and Space Administration

Lewis Research Center

Cleveland, Ohio 44135

Work performed for

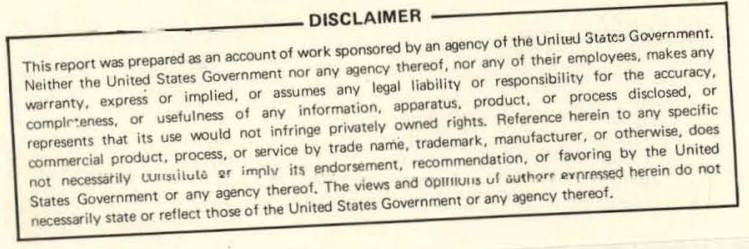

U.S. DEPARTMENT OF ENERGY

Fossil Energy

Office of Coal Utilization and Extraction

Washington, D.C. 20545

Under Interagency Agreement DE-Al01-77ET13111

Prepared for

Joint Power Conference

Denver, Colorado, October 17-21, 1982 


\section{COMBUSTION OF COAL GAS FUELS IN A STAGED COMBUSTOR}

T. J. Rosfjord and J. B. McVey

United Technologies Research Center

United Technologies Corporation

East Hartford, Connecticut

R. A. Sederquist

Power Systems Division

United Technologies Corporation

South Windsor, Connecticut

\section{F. Schultz}

NASA Lewis Research Center

Cleveland, Ohio

\section{ABSTRACT}

Gaseous fuels produced from coal resources have been considered for use in industrial gas turbines. Such fuels generally have heating values much lower than the typical gaseous fuel, natural gas; the low heating value could result in unstable or inefficient combustion. Additionally, coal gas fuels may contain ammonia which if oxidized in an uncontrolled manner could result in unacceptable $\mathrm{NO}_{x}$ exhaust emission levels. Previous investigations have indicated that staged, rich-lean combustion represents a desirable approach to achieve stable, efficient, low NO $x$ emission operation for coal-derived liquid fuels containing up to 0.8-wt pct nitrogen. An experimental program has been conducted to determine whether this fuel tolerance can be extended to include coalderived gaseous fuels. The results of tests with three nitrogen-free fuels having heating values of 100,250 , and $350 \mathrm{Btu} / \mathrm{scf}$ and a $250 \mathrm{Btu} / \mathrm{scf}$ heating value doped to contain 0.7 pct ammonia are presented.

NOMENCLATURE

$$
\begin{aligned}
& \text { EHV - Enhanced heating value fuel (349 Btu/SCF) } \\
& \text { f/a - Overall fuel-air ratio } \\
& \text { K15 - Factor to correct emissions to } 15 \% \\
& \text { oxygen in exhaust } \\
& \text { LHV - Low heating value fuel (103 Btu/SCF) } \\
& \text { MHV - Medium heating value fuel (258 Btu/SCF) } \\
& \text { MHV-FN - MHV fuel containing fuel-bound nitrogen } \\
& \text { T/C - Type B thermocouple } \\
& \phi_{\mathrm{p}} \quad \text { - Primary zone equivalence ratio }
\end{aligned}
$$

\section{INTRODUCTION}

Coal represents an ahundant energy resource in the United States. Currently, technology is being developed to optimize the manner in which this fuel will be utilized. Several alternatives exist including combusting the solid fuel in furnaces, liquefying or gasifying the coal for use in furnaces or gas turbine combustors, or some combination of these strategies. Selection of the most desirable appruach will depend on many factors, one of which will likely be the environmental impact of the fuel combustion process. Of particular concern will be the level of undesirable combustor exhaust emissions, including nitric oxides $\left(\mathrm{NO}_{\mathrm{x}}\right)$, carbon monoxide (CO), and smoke.

Coal-derived fuels can represent a significant challenge to attempts to control these species. Coal-derived fuels can be hydrogen deficient, promoting increased smoke emissions, and can contain levels of nitrogen which, if fully oxidized, will result in unacceptable $\mathrm{NO}_{x}$ levels. Fuels produced by a coal gasification process would be deficient in volumetric heating value, possessing energy densities from 10 to $35 \%$ of the heating value of natural gas. Combustor stability and efficiency may be affected by utilizing this product. Additionally, the gaseous fuel may contain ammonia (its presence is dependent on the fuel cleanup process employed) which could be oxidized to undesirable levels of $\mathrm{NO}_{\mathrm{x}}$. Recent test results (1) with a staged, rich/lean combustor have indicated a considerable tolerance for variation in the liquid fuel properties while retaining a low exhaust emission characteristic. In this combustor, the fuel is first partially-oxidized in a fuel-rich chamber which favors the conversion of fuel nitrogen to molecular nitrogen rather than $\mathrm{NO}_{\mathrm{x}}$. The balance of the total airflow is rapidly mixed in a quench section with the rich chamber efflueut. Rapid mixing of the secondary air (quench air) and rich chamber gases is necessary to avoid long flow residence times for near-stoichiometric mixtures and, consequently, to avoid significant formation of $\mathrm{NO}_{\mathrm{x}}$ by a thermal fixation mechanism. The mixture is subsequently fully oxidized in a fuel-lean combustor designed to permit consumption of residual hydrocarbons and $C O$. Such a rich-lean combustor has demonstrated the ability to achieve stable, efficient, low-smoke combustion with distillate fuels with hydrogen content down to $9 \%$ (wt), while restricting $\mathrm{NO}_{x}$ emissions to $40 \mathrm{ppm}$ despite fuel nitrogen levels up to $0.8 \%$ (wt). The program objective was to determine if this fuel tolerance could be extended to include coal gas fuels.

Four test fuels were investigated including three non-nitrogen-bearing gas mixtures with higher heating values of 84,210 , and $284 \mathrm{~kJ} / \mathrm{mol}$ $(95,238$ and $322 \mathrm{Btu} / \mathrm{scf})$, and a $210 \mathrm{~kJ} / \mathrm{mol}$ heating value fuel doped with ammonia to produce a fuel nitrogen content of $0.5 \%$ (wt). The tests were performed at four conditions representative of industrial gas turbine operating conditions.

\section{TEST APPARATUS}

The test apparatus is shown schematically in Figure 1. The rig consisted of an air inlet section, a model rich/lean combustor and an exhaust section. Air was supplied to the test cell at flow rates up to $1.8 \mathrm{~kg} / \mathrm{s}$ at pressures up 


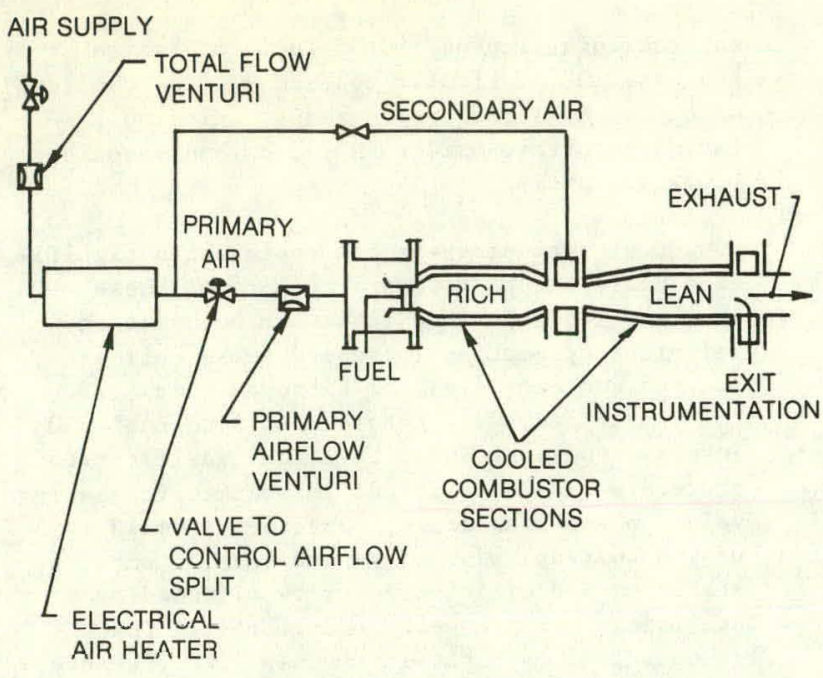

Fig. 1 Synthetic fuel combustor rig

to 4.0 MPa. An electrical resistance-type heater capable of heating airflows in excess of $1.8 \mathrm{~kg} / \mathrm{s}$ to $644^{\circ} \mathrm{K}$ was used; lesser airflows could be heated to higher temperatures (e.g., $1.1 \mathrm{~kg} / \mathrm{s}$ heated to $811^{\circ} \mathrm{K}$ ). The airflow which exited the heater was divided into a primary airflow, which fed the rich-stage combustor, and a secondary airflow which was injected through the combustor quench section. Variations in the primary-secondary airflow split were achieved by actuating a pneumatic control valve located in the primary air line; a high temperature gate valve located in the secondary air line provided the supply system pressure drop necessary for control. A calibrated venturi was located in the primary line to meter the primary airflow and hence permit calculation of the rich combustor equivalence ratio. The secondary airflow rate was calculated as the difference of the total and the primary airflow rates.

The model combustor used in this study consisted of four components (Figure 2):

- Fuel preparation section

- Fue1-rich combustion section

- Air quench section

- Fue1-lean combustion section

The fuel preparation section consisted of a single fuel injector which was centrally mounted in an annular, vane-type swirler. The $5.08-\mathrm{cm}$ diameter swirler was constructed from 18 equallyspaced vanes oriented at a $45^{\circ}$ angle to the combustor axis; it was recessed approximately $3.05 \mathrm{~cm}$ from the rich chamber inlet.

A direct injection technique was used in this program. No attempt was made to premix the fuel with air prior to injection into the combustor. Rather, the gaseous fuel was injected from a simple nozzle directly into the rich combustion

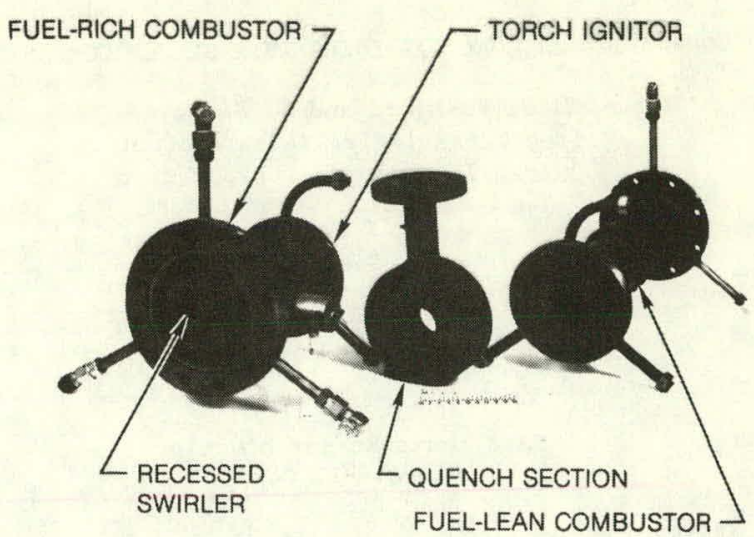

Fig. 2 Subscale rich-lean combustor hardware

chamber. The device used was a $2.54-\mathrm{cm}$ diameter closed-end tube containing eight equally-spaced holes around the tube circumference at the closed end and nine small holes in the end cap (Figure 3 ). The total injection area was specified to

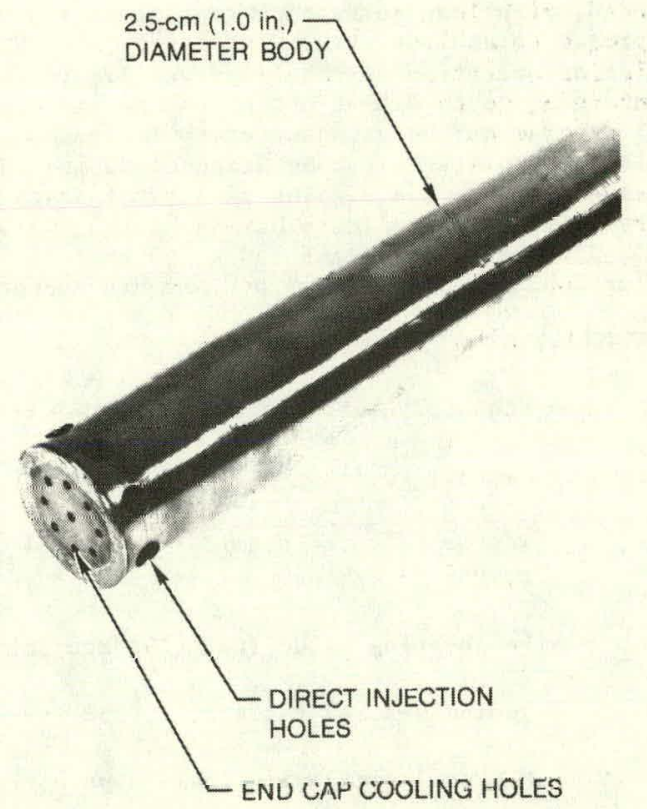

Fig. 3 Gaseous fuel injector

achieve a desired pressure drop; the end cap open area was set to pass $10 \%$ of the fuel f1ow to both cool the cap and blow off recirculating f1nw regions which might contribute to the stabilization of flame at the injector face. Combustor shakedown tests were conducted using a propane/ nitrogen mixture having a heating value of 265 $\mathrm{kJ} / \mathrm{mol}$. These tests indicated that stable combustion was not achieved under certain conditions due to what appeared to be feed-systemcoupled flow instabilities. A high pressure-drop injector (approximately $0.95 \mathrm{MPa}$ at the baseload 
fuel flow) alleviated this condition to a large degree. Except for the one instance noted hereafter, the reported data were acquired with injectors which operated with this pressure-drop level. At the end of the experimental program, an additional test was performed to determine whether a lesser injector pressure drop would be acceptable for use with the $\mathrm{CO} / \mathrm{H}_{2} / \mathrm{CO}_{2}$ gas mixture (which was expected to provide greater acabilily than the propane-nitrngen gas used when burner instability was observed). The results (Section III) iudicatcd that stable rombustion could be sustained for an injector pressure drop as luw as $3.4 \mathrm{kPa}$. Iwo different injectors were used in the test program. Fur the medium and enhanced heating value fue $1 \mathrm{~s}, 0.24-\mathrm{cm}$ diameter injection holes were specified. For the low heating fuel, which required considerably greater mass flow rates, $0.46-\mathrm{cm}$ diameter injection holes were specified. Each fuel injector was located in the rich combustion chamber such that the injection plane was $7.62 \mathrm{~cm}$ downstream from the swirler.

The fuel-rich combustion chamber was a $12.7-\mathrm{cm}$ diameter cylindrical section, $30.2-\mathrm{cm}$ long, with $3.0-\mathrm{cm}$ long conical sections at both the inlet and exit (Figure 4). The total volume of this chamber was $4540 \mathrm{~cm}^{3}$; the surface area

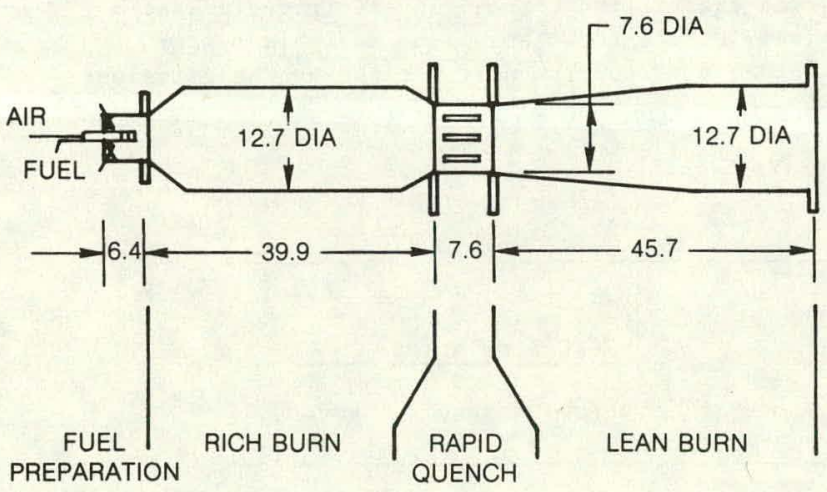

\section{ALL DIMENSIONS IN CENTIMETEHS}

Fig. 4 Subscale rich-1ean combustor configuration

was $1616 \mathrm{~cm}^{2}$. The entire chamber was doublejacketed to allow a nominal $1.58-1 / \mathrm{s}$ water coolant flow rate. An $\mathrm{H}_{2} / \mathrm{O}_{2}$ torch was incorporated for use as an igniter. The quench section was a $7.62-\mathrm{cm}$ diameter cylindrical section, $7.62-\mathrm{cm}$ long, containing eight pairs of slots through which the secondary airflow was admitted (Figure 5). The fuel lean combustor consisted of a $26.9-\mathrm{cm}$ long conical diffuser followed by a $12.7-\mathrm{cm}$ diameter cylindrical section. The overall length from the quench section exit to the exhaust measurement plane was $45.7 \mathrm{~cm}$. The lean combustor was also doublejacketed; the water coolant used for the rich burner was routed in series fashion to the lean burner.

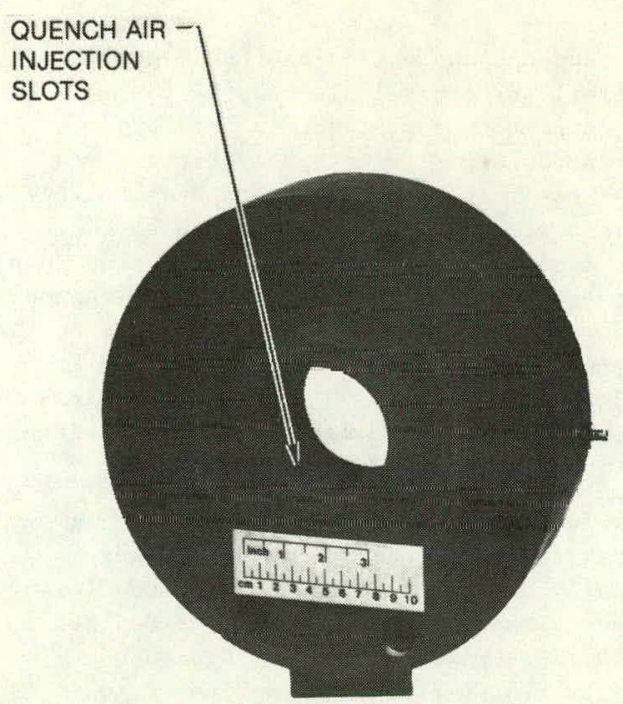

Fig. 5 Quench section of subscale combustor

The exhaust section contained two important components: a viewport, and a back pressure valve. The viewport contained a 7.62-cm diameter quartz window which provided direct observation of the combustor exit plane via an available closed-circuit television system. The video image was monitored in the control room and recorded with an audio track to provide a permanent record of the test sequence. A remotelyoperated back pressure valve was used to control the test section pressure. A high pressure water quench was used to reduce the gas temperatures upstream of the valve to less than $700^{\circ} \mathrm{K}$.

\section{TEST FUELS AND FUEL DELIVERY SYSTEMS}

The four test fuels used in this investigation are specified in Table 1 . The mixtures ranging in higher heating value from 88.2 to 309 $\mathrm{kJ} / \mathrm{mol}$ are representative of the products of coal gasification processes. The baseline fuel was a $40 \% \mathrm{CO} / 40 \% \mathrm{H}_{2} / 20 \% \mathrm{CO}_{2}$ (vol) mixture supplied hy a vendor in a multiple-tube trailer. Analyses of the delivered mixture indicated that the deviation from the above nominal values was less than 2 percentage points. This mixture had a higher heating value of $227 \mathrm{~kJ} / \mathrm{mol}$ and was referred to as the medium heating value (MHV) fuel. It represented the heating value from an oxygen-blown gasifier such as a Texaco gasifier (see Table 1 for typical gas compositions). The other three fuels were prepared by mixing an additional component to the baseline fuel. Nitrogen was added to the baseline fuel to produce a low heating value (LHV) fuel with a heating value of $91 \mathrm{~kJ} / \mathrm{mol}$. This product is typical of that produced by air-blown gasifiers. Propane was blended with the baseline fuel to produce an enhanced heating value (EHV) fuel with a heating value of $308 \mathrm{~kJ} / \mathrm{mole}$. The addition of a hydrocarbon resulted in a heating value representative of the higher heating value product 
from an oxygen-blown moving-bed LURGI gasifier (see Table 1 for typical gas compositions). The major hydrocarbon constituent in this type gasifier product gas is methane. Propane was used in these tests because of its availability at the test stand. Ammonia was added to the baseline fuel at a level sufficient to produce a fuel nitrogen content of $0.5 \%$ by weight. Ammonia is a potential gasifier product, depending on the gas cleanup system employed. The level of conversion of ammonia to $\mathrm{NO}_{x}$ exhaust emissions was documented by tests with this medium heating value - fuel nitrogen (MHV-FN) fuel.

The fuel mixtures were prepared on-1ine using a system in which each component was individually metered and regulated. Actuation of the proper subsystems resulted in the desired test fuel. All mixtures passed through $a$ $0.68 \mathrm{MPa}$ saturated steam heat exchanger to elevate the fuel temperature to approximately $433^{\circ} \mathrm{K}$. Combustors which are closely coupled to cual gasifiers will receive heated fuel; the level of heating depends on the fuel cleanup technique (temperature) and energy recovery (regenerative heat exchange) in the system. The $433^{\circ} \mathrm{K}$ level used in the present program reflected a facility 1 imit for the required fuel flowrates.

\section{INSTRUMENTATION}

The test apparatus was instrumented in accordance with standard practices; details are published in Ref. 2. The total airflow was metered using a calibrated venturi located upstream of the air heater; the venturi was sized to operate in the choked mode for all test conditions. The primary airflow was metered by another calibrated venturi; this venturi operated with pressure ratios between 0.55 and 0.75 . The flowrates of the baseline fuel, nitrogen and ammonia were metered by venturis; propane flowrate was determined using a calibrated turbine meter. Pressures and temperatures were measured at various locations by use of pressure transducers and thermocouples having appropriate calihration ranges. The combustor exit ronditions were documented by use of a five-port ganged sampling probe, a three-point thermocouple rake, and a smoke probe (Figure 6).

The water-cooled sampling probe spanned the combustor diameter, and contained five, $0.86-\mathrm{cm}$ diameter inlet orifices. The probe was designed to achieve an aerodynamic quick-quench of the captured streams in order to minimize chemical reaction within the probe. The captured sample was transferred through an electrically-heated sample line to an emissions analysis system capable of continuously monitoring the emissions

TABLE 1. COAL GAS TEST FUELS

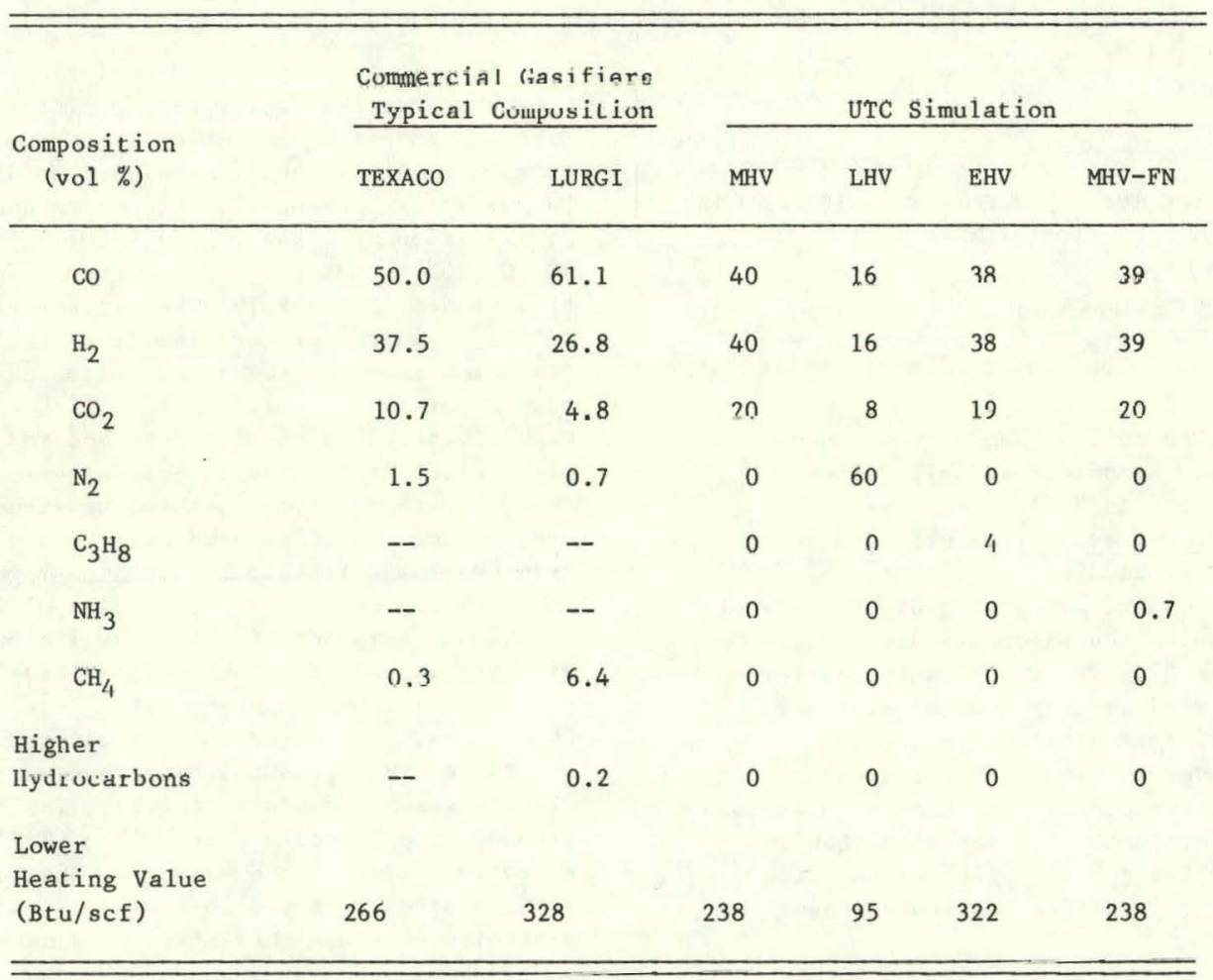


of carbon monoxide, oxygen, carbon dioxide, unburned hydrocarbons, and oxides of nitrogen. A water-cooled smoke probe was designed in accordance with specification SAE ARP1179. The probe, which had a sample inlet diameter of 1.9 $\mathrm{mm}$, was sized to isokinetically sample the gas stream at the baseload condition.

Three PT6RH/PT30RH thermocouples and vented radiation shields were mounted on a water-cooled strut. The material used for the exposed portions of the thermocouple sheath and the radiation shield was a platinum alloy which provided a significant temperature safely margin (maximum operating temperature of $1867^{\circ} \mathrm{K}$ ).

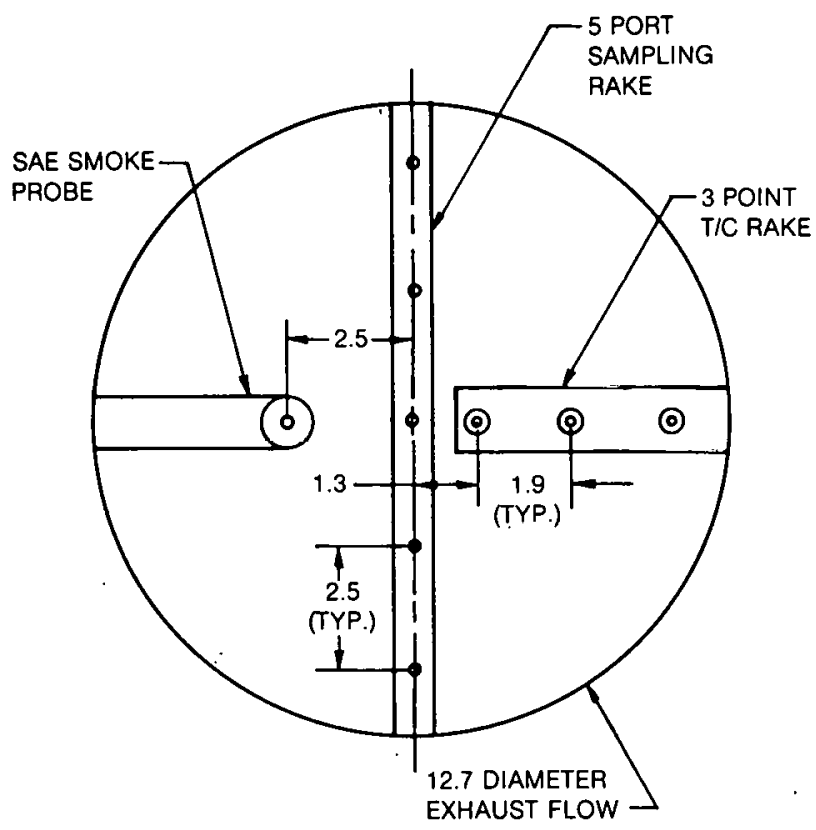

ALL DIMENSIONS IN CENTIME'I'IERS

Fig. 6 Exit plane instrumentation (viewed downstream)

\section{DATA ACQUISITION AND REDUCTION}

Test data were recorded by means of an automatic data acquisition system which recorded the information on magnetic tape for subsequent computer processing. Performance parameter definitions were those conventionally used. The concentration of exhaust species was corrected to reflect a standardized gas stream containing 15 percent oxygen according to:

(Corrected concentration $=$ measured concentration $\star \mathrm{K} 15)$

$$
\mathrm{K} 15=\frac{0.2096-0.15}{0.2096-\mathrm{X} 02}
$$

The heat flux, representing both convective and radiative contributions to the primary combustor coolant: was calculated from the temperature rise of the coolant.

\section{TEST CONDITIONS}

Tests were performed over the matrix of conditions indicated in Table II. The general intent was to establish emissions and heat load characteristics for each test fuel to determine the effect of combusting coal-derived gaseous fuels in a staged burner. The conditions included design-point conditions (Conditions 1, 2 3) representing burner operation at peak, baseload, and 50-percent power levels for a typical industrial gas burner. The fourth condition was reduced-pressure scaling of the peak-power design point (Peak-Low P); both pressure and airflow were reduced to maintain constant combustor residence time. This condition also served as the basis for two additional tests (Conditions 5, 6) to determine the effect of changing the primary combustor equivalence ratio $\left(\phi_{p}\right)$ on the combustor emissions. Together, these three tests were referred to as a signature series, and were generally performed by holding the total airflow and the split of airflow between the primary and secondary combustors constant while varying the fuel flow. This approach permitted changes in $\phi_{p}$ while keeping the primary combustor residence time constant. This technique is the desired one to determine the effectiveness of the primary combustor to minimize production of $\mathrm{NO}_{x}$ by either conversion of fuel nitrogen to $\mathrm{NO}_{x}$ or formation of $\mathrm{NO}_{x}$ because of locally near stoichiometric fuel-air ratios. With this approach the overall fuel-air ratio [(f/a) ov], and hence the secondary temperature, varied as $\phi_{p}$ was changed. Because of the variation of iean combustion temperature levels associated with this mode of testing, the results should be used only to judge the $\mathrm{NO}_{\mathrm{x}}$ behavior, not the $\mathrm{CO}$ emission behavior, of the combustor. These six tests were performed for all test fuels and are referred to as the basic test conditions. Some of the preliminary test results indicated that $c 0$ control, not $\mathrm{NO}_{x}$ control, was the greater challenge. In order to assess the influence of $\phi_{p}$ on co emission levels for a constant ( $f / a$ )ov, ${ }_{a}$ different siguatuic tcot was performed.

In these tests, the total airflow and the fuel flow were held constant, but the airflow split between the two combustion chambers was varied to attain $\phi_{p}$ changes. In this approach the primary combustor residence time and the quench zone mixing process changed because of differing primary and secondary airflow rates.

\section{RESULTS}

Common Combustion Chatacleristics There were two common characteristics for all combustion tests performed in this program. First, no smoke emissions were detected for any of the test fuels. Samples acquired according to ARP 1179 would be evaluated as having an SAE smoke number of two or less. 
Second, the test fuels ignited easily and burned stably. Ignitability was not rigorously evaluated as the torch ignitor system delivered energy levels in excess of that available from conventional spark devices. It was observed, however, that unlike the propane/nitrogen fuel mixture used during shakedown testing, the coal gas fuels ignited promptly at all of the test conditions. Stable combustion was always achieved.

Test Results for Medium Heating Value (MHV) Fuel Tests were performed with the baseline MHV fuel to determine the emissions and heat load characteristics. Tests were performed under six basic test conditions (Table II), and at additional conditions selected to provide information on the influence on performance and emissiono of injector pressure drop and higher combustor exit temperature.

The NO $x$ emissions corresponding to an exhaust with 15 percent oxygen obtained from tesls at che basic six conditinns are plotted in Figure 7. Ultra-low $\mathrm{NO}_{x}$ levels were attained for all conditions, with the highest being 25 ppm at peak condition. The uncorrected NO data revealed a square root dependence on combustor pressure, identical to the commonly accepted pressure dependence for thermally-produced $\mathrm{NO}_{x}$. No strong dependence of $\mathrm{NO}_{x}$ on $\phi_{p}$ was observed from the signature test results although there was a slight decrease in NO with increasing $\phi_{\mathrm{P}}$. The absence of a strong dependence coupled with the low No $x$ levels observed and the previously noted thermal-NO $x$ pressure dependence indicated that little No $x$ was discharged from the $r i c h$ stage and exhaust levels resulted from production of $\mathrm{NO}_{x}$ in the quench and fuel-lean combustor sections. Therefore, further NO reduction would likely not result from rich-stage uptimization, but rather from quench and lean-combustor optimization.

The Co emissions were $150 \mathrm{ppm}$ at the peak test condition, increasing to $500 \mathrm{ppm}$ at the 50 percent power condition. This latter value would likely not be acceptable for a practical installation as it reflects a 0.5 percent combustion inefficiency. An improved lean burner design (e.g., longer residence time, air staging to produce a higher temperature secondary zone) could reduce the co emissions levels.

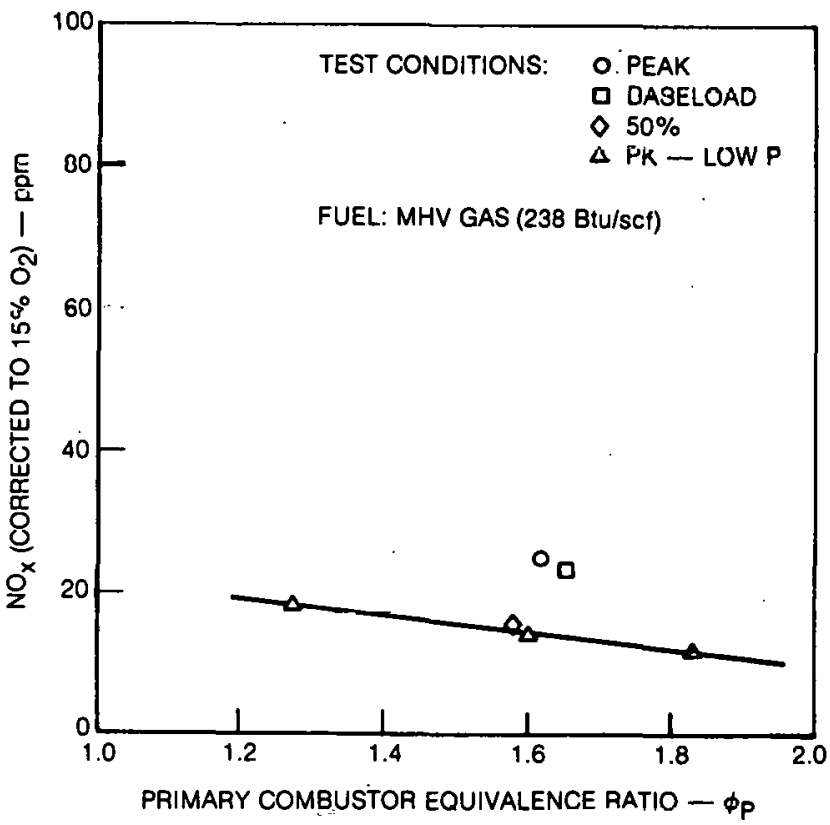

Fig. 7 Nny dependenoc on priltaly cumbustor equiivalence ratio for MIV fuel

TABLE II. TEST CONDITIONS

\begin{tabular}{lccccc}
\hline Condition & $\begin{array}{c}\text { Total } \\
\text { Airflow } \\
\mathrm{kg} / \mathrm{s}\end{array}$ & $\begin{array}{c}\text { IuleL } \\
\text { Temperature } \\
{ }^{\circ} \mathrm{K}\end{array}$ & $\begin{array}{c}\text { Combustor } \\
\text { Pressure } \\
\text { MPa }\end{array}$ & $\begin{array}{c}\text { Exit } \\
\text { Temperature } \\
{ }^{\circ} \mathrm{K}\end{array}$ & $\phi_{\mathrm{p}}{ }^{*}$ \\
\hline 1. Peak & 1.36 & 672 & 1.37 & 1356 & 1.6 \\
2. Baseload & 1.18 & 644 & 1.24 & 1.367 & 1.6 \\
3. Su percent & 0.73 & $53 j$ & 0.69 & 1367 & 1.6 \\
4. Pk-Low P & 0.34 & 672 & 0.34 & 1367 & 1.6 \\
5. Signature & 0.34 & 672 & 0.34 & Variable & 2.4 \\
6. Signacure & 0.34 & 672 & 0.34 & Variable & 1.4 \\
\hline
\end{tabular}

*Primary combustor equivalence ratio $\left(\phi_{p}\right)$ target values are indicated. Actual test values depended upon emission characteristics determined from signature test series. 
The overall heat load on the primary combustor wall was determined from the temperature rise in the primary combustor coolant. An average heat flux of $4.73 \times 10^{5} \mathrm{~J} / \mathrm{m}^{2} \mathrm{~s}$ was transferred to the wall in the signature tests, independent of $\phi_{p}$. Tests with liquid fuels (Ref. 1) have indicated a dependence on $\phi_{p}$ because of the generation of carbon particles. The absence of smoke emissions and this independence of heat load are mutually consistent features expected when combusting coal gas fuel. The heat load nearly doubled for operation at the peak condition, becoming $8.2 \times 10^{5} \mathrm{~J} / \mathrm{m}^{2} \mathrm{~s}$. This is attributed both to an increased convective heat transfer because of higher airflows, and increased radiative heat transfer due to the emissivity increase associated with pressure elevation. Calculations indicate that the contribution from both processes approximately doubled.

A signature test series was performed to determine the influence of elevating the combustor exit temperature to approximately $1644^{\circ} \mathrm{K}$ on the exhaust emissions. In lhis signature series, the overall fuel-air ratio was held constant with $\phi_{p}$ variation achieved by changing the division of airflow between the primary and secondary combustors. Figure 8 depicts the corrected NO $x$ and $c 0$ levels attailled for operation at exit temperatures of $1644^{\circ} \mathrm{K}$ and $1367^{\circ} \mathrm{K}$. Ultralow valucs of these species were at.tained for the $1367^{\circ} \mathrm{K}$ temperature test series. The No

FUEL: MHV GAS (238 Btu/scf) SPECIE: $\begin{aligned} & \triangle \mathrm{NO} \\ & \mathrm{O}\end{aligned}$

OPEN SYMBOLS - EXIT TEMPERATURE $=1370 \mathrm{~K}$ CLOSED SYMBOLS - EXIT TEMPERATURE $=1650 \mathrm{~K}$

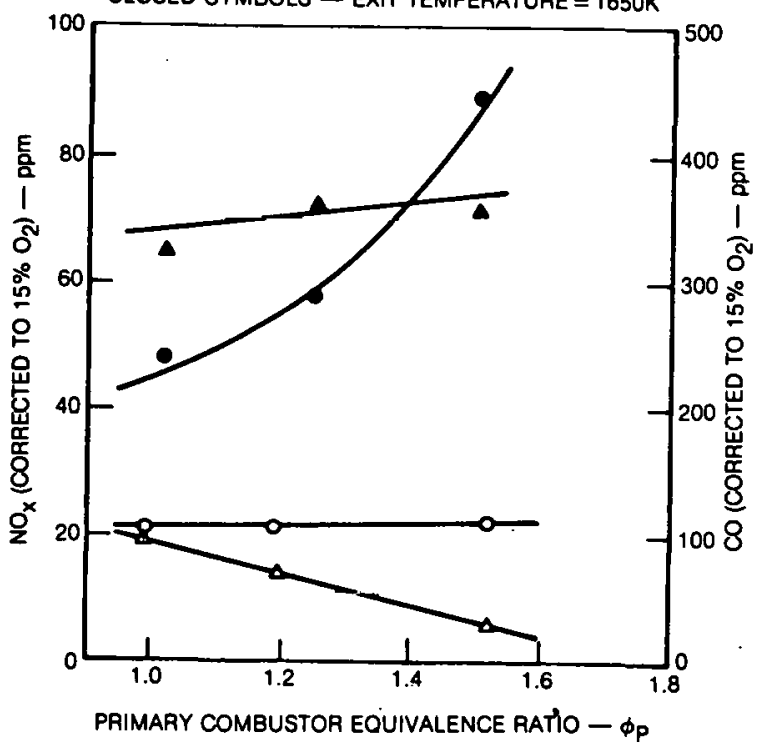

Fig. 8 Comparison of exhaust emissions for operation at exit temperatures of $1370 \mathrm{~K}$ and $1650 \mathrm{~K}$ increased as $\phi_{p}$ approached unity suggesting that some thermal fixation of nitrogen was occurring in the rich combustor. Tests at the elevated temperature resulted in increased levels for both $\mathrm{NO}_{x}$ and $\mathrm{CO}$. When analyzed, this result implied that the combustor fluid mechanics have been significantly altered. Despite the higher lean-burner temperature, and consequently accelerated co consumption rates, higher co levels were recorded. Therefore, the level of co entering the lean burner must have been higher than experienced for the $1367^{\circ} \mathrm{K}$ temperature tests and/or the $\mathrm{CO}$ and secondary air must not have been well mixed in the quench section. It was likely that both of these influences existed. To achieve the higher exit temperature, the fuel flow was increased by approximately 50 percent. Additionally, to achieve the same $\phi_{p}$, the primary airflow was increased by a similar percentage resulting in more than twice the mass flow through the rich burner for the elevated temperature condition. The reduced residence time at this combustor loading could curtail oxidation of the $\mathrm{CO}$, resulting in excessive $\mathrm{CO}$ levels exiting the rich combustor. This concept is supported by the observation of a decreasing co level as $\phi_{\mathrm{p}}$ approached unity. The mixing processes occurring in the quench section were also degraded. The higher primary airflow resulted not only in a greater rich combustor effluent but also in a reduced quench airflow. The percentage penetration of the air jets emanating from the quench slots would be decreased and the mixing with the primary combustor gases would be less vigorous. Hence, some portions of the gas stream may have been deficient in oxidizer while others were over-oxidized (an over-cooled by the quench air). The observed No $x$ levels support this characterization. The substantial No $x$ increase for the high exit temperature tests reflected a sluggish transition from fuel-rich to fuel-lean conditions, permitting additional formation of thermal No $x$. It is apparent from these results that achievement of lowe $r \mathrm{NO}_{x}$ and $\mathrm{CO}$ emissions at the higher combustor cxit temperature would require re-design of the combustor to optimize the rich zone residence time and penetration of secondary air in the quench zone.

Comparison of Test Results for Medium Heating Value - Fuel Nitrogen (MHV-FN) And MHV Fuels The $\mathrm{NO}_{x}$ levels obtained for both the MHV and MHV-FN fuel are presented for comparison in Figure 9. The MHV fuel did not contain ammonia; the MHV-FN contained 0.7 percent (vol) $\mathrm{NH}_{3}$ to achieve a fuel nitrogen content of 0.5 percent (wt). Substantially higher $\mathrm{NO}_{x}$ emissions were attained with the MHV-FN fuel reflecting conversion of the added ammonia to No $x$, although No $x$ emissions well below the EPA limit can still be readily achieved. The increase in NO does not reflect a high absolute value of conversion rate, however. That is, because of the relatively low heating value of the fuel (i.e., 


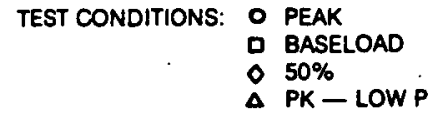

OPEN SYMBOLS - MHV FUEL (23B BtU/sC). CLOSED SYMBOLS - MHV-FN FUEL $\left(0.7 \% \mathrm{NH}_{3}, 0.5 \%\right.$ FN)

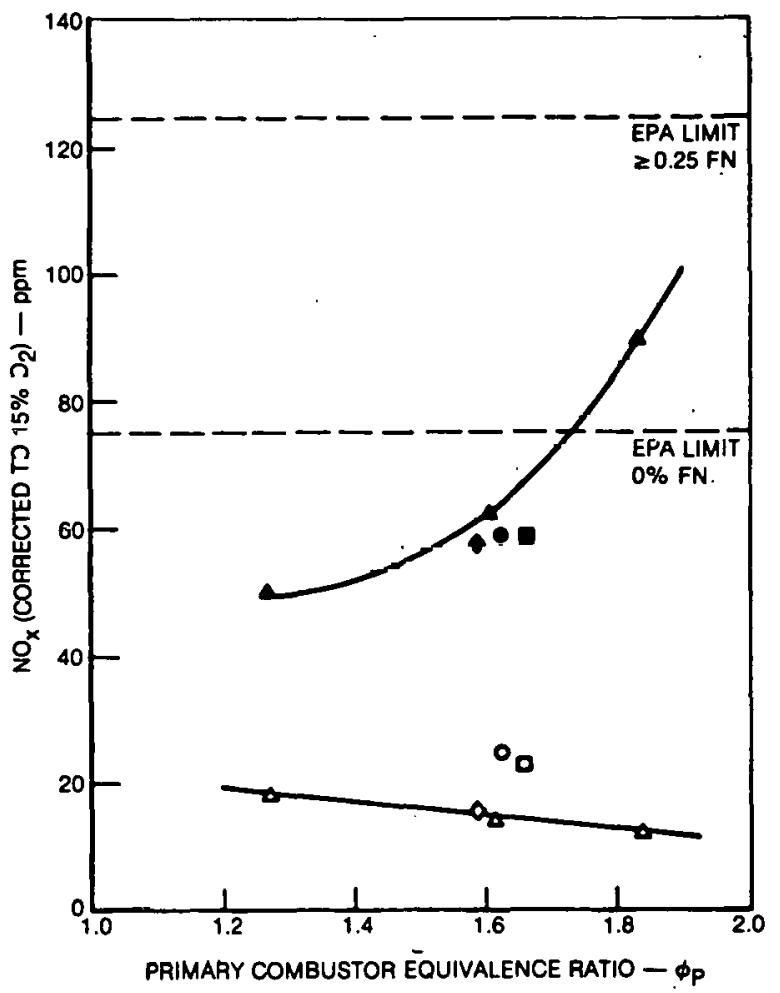

Fig. 9 Effects of $\mathrm{MH}_{3}$ addition on $\mathrm{NO}_{x}$ signature

approximately 25 percent of the heating value of natural gas) relatively large values of fuel-air ratio were required to reach the desired exit temperature. The quantity of ammonia added represented a potential $\mathrm{NO}_{x}$ increase of between 650-1000 ppm if it were fully converted, whereas actual increases ranged between $25-80 \mathrm{ppm}$. At low-rich-zone equivalence ratios where CO emission levels are acceptable, a $\mathrm{NH}_{3}$ conversion level of less than 5 percent was measured.

COMPARISON OF TEST RESULTS FOR ENHANCF.D HEATING VALUE (BHV) AND MHV FUELS

A metered quantity of propane was added to the MHV fuel to produce EHV fuel simulating a hydiucalbull concaining a product gas heating value representative of a moving-bed gasifier such as a LURGI coal gasifier, The EHV fuel mixture contained approximately 4 percent (vol) propane, a quantity sufficient to raise the heating value from 227 to $308 \mathrm{~kJ} / \mathrm{mol}$ but not enough to result in any unburned hydrocarbon or smoke exhaust emission.

The NO levels attained using the EHV fuel are compared to the MHV fuel results in Figure

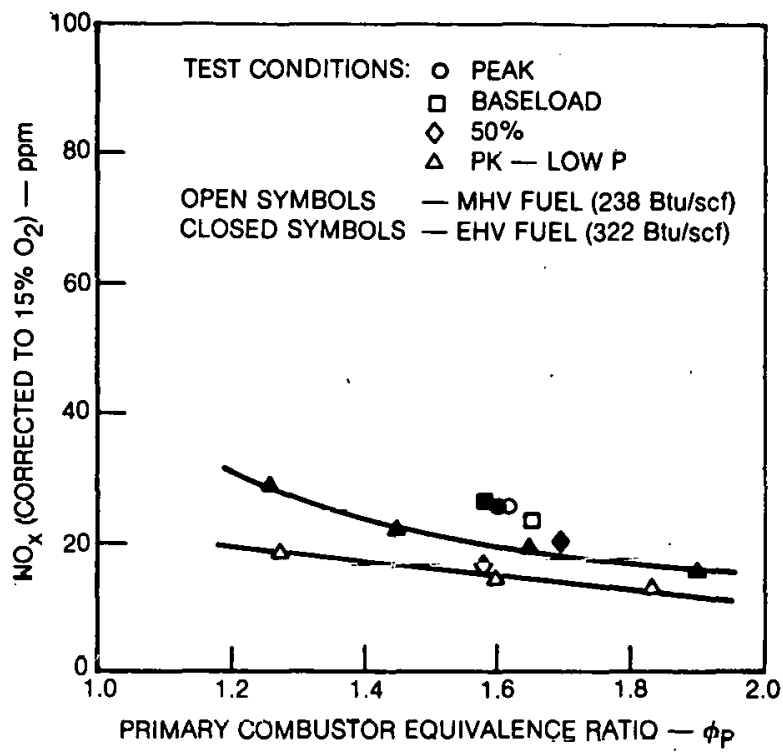

F1g. 10 Comparison of $\mathrm{NO}_{x}$ signature for MHV and EHV fuels

10. Very 1ittle change was evident; ultra-low $\mathrm{NO}_{x}$ levels were again attained. The $\mathrm{NO}_{x}$ emissions were slightly higher at all conditions than achieved for the MHV fuel because of slightly higher flame temperatures associated with the heating value enhancement.

The carbon monoxide emissiuns and the combustor heat load were also slightly higher than achieved for the MHV fuel. Co emissions reached $250 \mathrm{ppm}$ and $680 \mathrm{ppw}$ at the peak and 50 percent power test conditions, respectively. This result was contrary to expectation, as higher rich-combustor temperatures would be expected for the EHV fuel and the mixing processes would not be altered, since it was not required to make large changes in the primary/quench airflow split. It is noted that the reported $c 0$ value for the 50 percent condition was obtained at $\phi_{p}=1.7$, higher than the corresponding value in the MHV test data. Hence somewhat higher $C O$ would be expected for this condition. Tho heat load increased approximately 10 percent, reaching $9.1 \times 10^{5} \mathrm{~J} / \mathrm{m}^{2} \mathrm{~s}$ at the peak condition, reflecting the increased combustion temperatures.

Comparison of Test Results for Low Heating Value (LHV) and MHV Fuels

A liw hearing value (IIIV) fuel was produced on-line by mixing approximately 40 percent (vol) MHV fuel with 60 percent (vol) nitrogen. The low liealing value of this mixture required fuel flowrates quadruple che MHV fuel flowrates to achieve the same combustor exit temperature. Thio factor is greacer than the ratio of fuel heating values because the additional fuel flow represents a significant mass addition which also must be heated. 
Ultra-low No values were achieved for all tests using LHV fuel; no reading greater than 9 ppm was observed. This characteristic was attributed to the fuel composition. Even when reacted in stoichiometric proportions, the fuel could only produce a $1200^{\circ} \mathrm{K}$ temperature rise because the nitrogen, acting as a diluent, absorbed some portion of the energy released during reaction. Hence, it prohibited the existence of high temperature regions necessary for significant $\mathrm{NO}_{x}$ formation.

The fuel characteristics also contributed to the presence of high levels of Co in the combustor exhaust. The exhaust $C O$ concentration depends upon the level of co entering the lean burner and the rate of co consumption within the lean burner. The high fuel flnwrates, and associated higher primary airflow rate, resulted in richcombustor residence times shorter than experienced for MHV fuel, with the gases at lower temperatures. Hence, it would be expected that higher co concentrations would exist at the rich combustor exit. Additionally, as with the MHV fuel tests at elevated exit temperatures, the increased primary airflow degraded the quench section effcctiveness. Thus, while rapid co burnup might have been possible, incomplete mixing would limit the efficiency. These trends were supported by the data obtained. Initial tests with $\phi_{p}$ values near 1,6 resulted in $C O$ concentrations exceeding $5000 \mathrm{ppm}$. Subsequent tests were performed at lower $\phi_{p}$ in an attempt to raise the co oxidation rates in the rich combustor. Figure 11 displays the Co levels for design point test conditions with $\phi_{p}$ near unity. As can be seen, small changes in $\phi$ dramatically affected

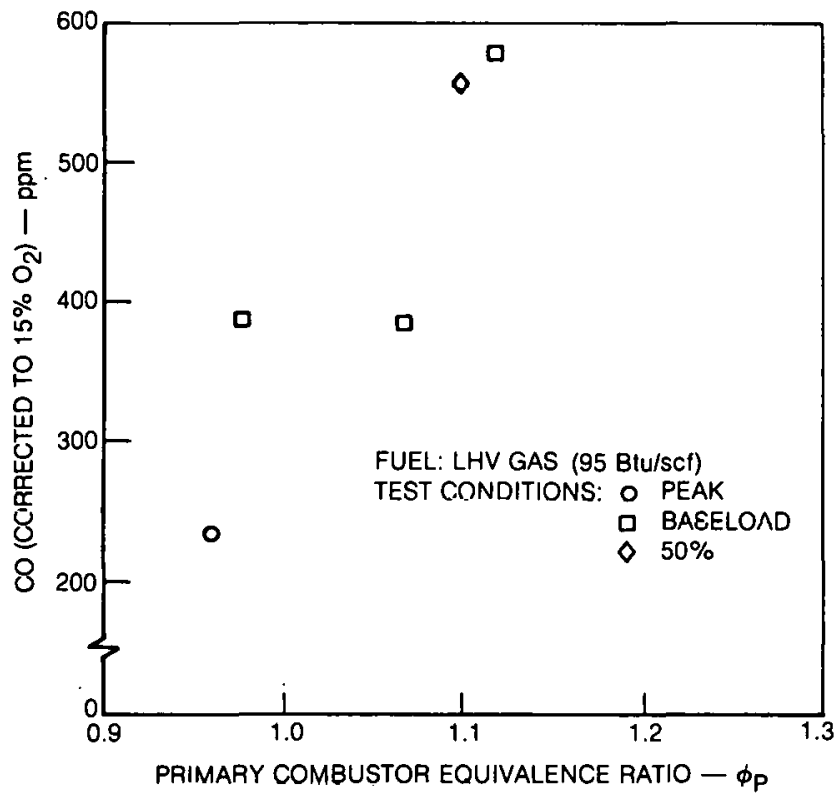

Fig. 11 co emission dependence on primary combustor squivalenre ratio for LHV fuel the co level. Furthermore, it was indicated that minimal co levels would be obtained for $\phi_{p}<1$. That is, fuel-rich operation was undesirable for the LHV fuel because of the attendant co levels. In limited additional tests, it was determined that a co level down to 9 ppm could be achieved at $\phi_{p}=0.75$. The combustor was stable at this condition, and because of the low flame temperatures the $\mathrm{NO}_{x}$ level was still only $8 \mathrm{ppm}$.

The extreme sensitivity of co level to primary stage equivalence ratio is explained in large measure by the sensitivity of primary zone Co production to primary zone equivalence ratio. If reactions proceeded to completion, the equilibrium levels of Co shown in Figure 12 would exist at the primary zone exit. As indicated, equilibrium CO levels for LHV fuel drop by three orders of magnitude as the primary zone equivalence ratio is changed from a value of 1.2 to 0.8 . The levels of $C O$ measured are close to the theoretical equilibrium levels which indicates that for LHV fuel most of the chemical reaction occurs in the primary zone, and little reaction in the lean zone.

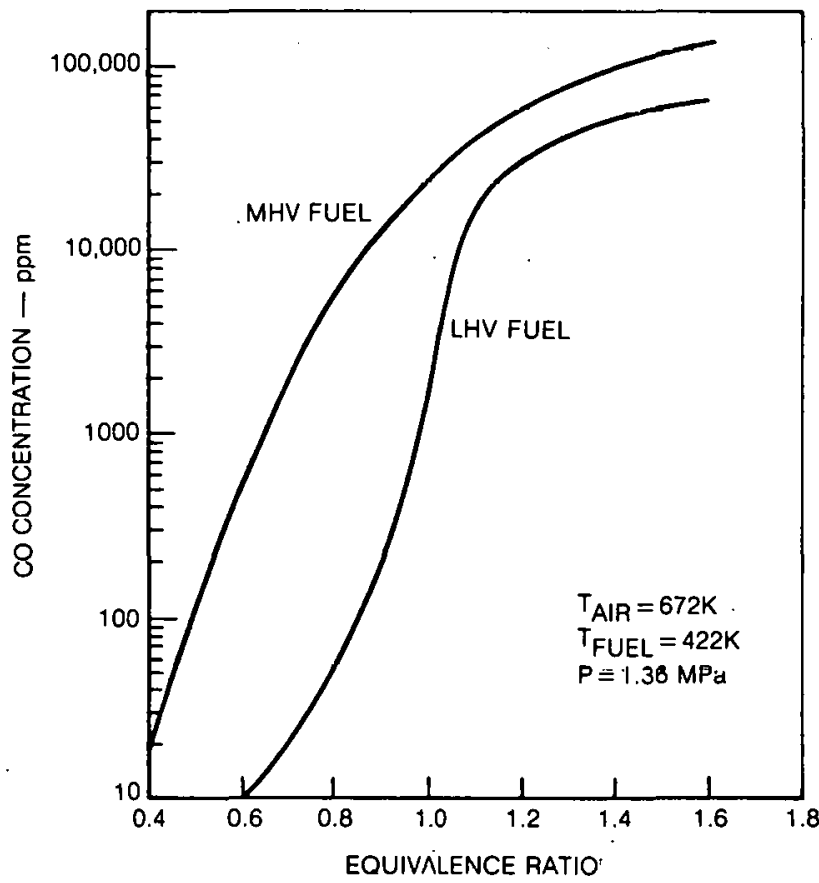

Fig. 12 Equilibrium CO levels for MHV and LHV fuels

\section{CONCLUSIONS}

The objective of this study was to evaluate the performance and emission characteristics of a rich-lean staged combustor fired on coal gas fuel. Tests were performed using four test fuels including three chemically bound nitrogenfree fuels with heating values of $84,210,284$ $\mathrm{kJ} / \mathrm{mol}(95,238,322 \mathrm{Btu} / \mathrm{scf}$, respectively) and a 
$210 \mathrm{~kJ} / \mathrm{mol}(258 \mathrm{Btu} / \mathrm{scf}$ ) fuel doped with 0.7 percent (vol) ammonia. The test results permit the following conclusions to be drawn:

1. Staged, rich-lean combustion represents the desirable approach to achieve ultra-low NO $x$ and co emissions for coal gas fuels with heating values of $210 \mathrm{~kJ} / \mathrm{mol}$ (238 Btu/scf) or higher.

2. Lean combustion represents the desirable approach to achieve ultra-low NO $x$ and co emissions for coal gas fuels with low heat ing values $(84 \mathrm{~kJ} / \mathrm{mol}(95 \mathrm{Btu} / \mathrm{scf}))$.

3. Staged combustion has the ability to limit $\mathrm{NH}_{3}$ in $\mathrm{N}_{\mathrm{x}}$ sonvoroion rates lu less than 5 percent. $\mathrm{NO}_{x}$ emissions beluw lhe EPA limit can readily be achieved.

\section{ACKNOWLEDGEMENTS}

This work was conducted by United Technologies Corporation under Contract DEN 3-149 "Low NO $x$ Heavy Fuel Combustor Concept Program", Phase IA Coal Gas Addendum. It encompasses the work under the Phase IA program (29 June 1981 to October 1981).

Contract DEN 3-149 was sponsored by the Department of Energy under the administration of the National Aeronautics and Space Administration, Lewis Research Center (DOE/NASA-LeRC). Donald Schultz of NASA/LeRC was the technical manager.

The UTC Program Manager was Fred Kemp (UTC/PSD) and the Technical Manager was Richard Sederquist (UCKC/PSD). Dr. Thomas Rosfjord was Primary Investigator for the Phase IA project at the United Technologies Research Center (UTRC). Alsu contributing to the technical effort of UTRC were Roy Pelmas, Dr. John McVey and Jan Kennedy.

\section{REFERENCES}

1. Rosfjord, T. J., et al.: Evaluation of Synthetic fiuel Character Effects on Rich-Lean Stationary Gas Turbine Combustion Systems. F.PRI Research Project RP1898-1, final Report, January 1982.

2. Rosf jord, T. J., et al.: Low NO $\mathrm{x}$ Heavy Fuel rinmhistor concept riugialu, Pha00 lA Coal Gas Addendum, Final Report, NASA CR-165577, January 1982. 


\begin{tabular}{|c|c|c|c|c|}
\hline $\begin{array}{l}\text { 1. Report No. } \\
\text { NASA TM- } 82987\end{array}$ & \multicolumn{2}{|c|}{ 2. Government Accession No. } & \multicolumn{2}{|c|}{ 3. Recipient's Catalog No. } \\
\hline \multicolumn{3}{|c|}{$\begin{array}{l}\text { 4. Title and Subtitle } \\
\text { COMBUSTION OF COAL GAS FUELS IN A STAGED COMBUSTOR }\end{array}$} & \multicolumn{2}{|l|}{ 5. Report Date } \\
\hline \multirow{3}{*}{\multicolumn{3}{|c|}{$\begin{array}{l}\text { 7. Author(s) } \\
\text { T. J. Rosfjord and J. B. McVey, United Technologies Corporation, } \\
\text { East Hartford, Connecticut, R. A. Sederquist, United Technologies } \\
\text { Corporation, South Windsor, Connecticut, and D. F. Schultz, Lewis } \\
\text { Research Center }\end{array}$}} & \multicolumn{2}{|c|}{$\begin{array}{l}\text { 6. Performing Organization Code } \\
778-14-10\end{array}$} \\
\hline & & & \multicolumn{2}{|c|}{$\begin{array}{l}\text { 8. Performing Organization Report No. } \\
\text { E-1419 }\end{array}$} \\
\hline & & & \multicolumn{2}{|l|}{ 10. Work Unit No. } \\
\hline \multirow{3}{*}{\multicolumn{3}{|c|}{$\begin{array}{l}\text { 9. Performing Organization Name and Address } \\
\text { National Aeronautics and Space Administration } \\
\text { Lewis Research Center } \\
\text { Cleveland, Ohio } 44135\end{array}$}} & \\
\hline & & & \multicolumn{2}{|c|}{ 11. Contract or Grant No. } \\
\hline & & & \multirow{2}{*}{\multicolumn{2}{|c|}{$\begin{array}{l}\text { 13. Type of Report and Period Covered } \\
\text { Technical Memorandum }\end{array}$}} \\
\hline \multirow{2}{*}{\multicolumn{3}{|c|}{$\begin{array}{l}\text { 12. Sponsoring Agency Name and Address } \\
\text { U.S. Department of Energy } \\
\text { Office of Coal Utilization and Extraction } \\
\text { Washington, D.C. } 20545\end{array}$}} & & \\
\hline & & & \multicolumn{2}{|c|}{$\begin{array}{l}\text { 14. Sponsoring Agency code-Report No } \\
\text { DOE/NASA/13111-12 }\end{array}$} \\
\hline \multicolumn{5}{|c|}{$\begin{array}{l}\text { 15. Supplementary Notes } \\
\text { Prepared under Interagency Agreement DE-AI01-77ET13111. Prepared for Joint Power } \\
\text { Conference, Denver, Colorado, October 17-21, 1982. }\end{array}$} \\
\hline \multicolumn{5}{|c|}{$\begin{array}{l}\text { 16. Abstract } \\
\text { Gaseous fuels produced from coal resources have been considered for use in industrial gas tur- } \\
\text { bines. Such fuels generally have heating values much lower than the typical gaseous fuel, natural } \\
\text { gas; the low heating value could result in unstable or inefficient combustion. Additionally, coal } \\
\text { gas fuels may contain ammonia which if oxidized in an uncontrolled manner could result in un- } \\
\text { acceptable } \mathrm{NO}_{\mathrm{x}} \text { exhaust emission levels. Previous investigations have indicated that staged, } \\
\text { rich-lean combustion represents a desirable approach to achieve stable, efficient, low } \mathrm{NO}_{\mathrm{X}} \text { emis- } \\
\text { sion operation for coal-derived liquid fuels containing up to } 0.8 \text {-wt pct nitrogen. An experimental } \\
\text { program has been conducted to determine whether this fuel tolerance can be extended to include } \\
\text { coal-derived gaseous fuels. The results of tests with three nitrogen-free fuels having heating } \\
\text { values of } 100,250 \text {, and } 350 \mathrm{Btu} / \mathrm{scf} \text { and a } 250 \mathrm{Btu} / \mathrm{scf} \text { heating value doped to contain } 0.7 \text { pct } \\
\text { anmonia are presented. }\end{array}$} \\
\hline \multicolumn{2}{|c|}{$\begin{array}{l}\text { 17. Key Words (Suggested by Author(s) ) } \\
\text { Coal syncrude; Stationary gas turbine engines; } \\
\text { Exhaust emission; Fuel combustion; Combus- } \\
\text { tion products; Coal gas; Coal gas combustion }\end{array}$} & \multicolumn{3}{|c|}{$\begin{array}{l}\text { 18. Distribution Statement } \\
\text { Unclassified - unlimited } \\
\text { STAR Category } 44 \\
\text { DOE Category UC-90f }\end{array}$} \\
\hline $\begin{array}{l}\text { 19. Security Classlf. Uof this } 1 \\
\text { Unclassif }\end{array}$ & $\begin{array}{r}\text { 20. Somirity Classir. Ih } \\
\text { Uncl }\end{array}$ & $\begin{array}{l}\text { ul this pogel } \\
\text { lassified }\end{array}$ & 21. No. of Pagas & 22. Price \\
\hline
\end{tabular}

* For sale by the National Technical Information Service, Springfield. Virginia 22161 